\title{
Pogranicze w warsztacie politologa
}

Marceli Kosman ${ }^{1}$

Link do artykułu:

http://pogranicze.uni.opole.p1/biblioteka/docs/nr1/kosman_nr1.pdf

Standard cytowania (APA):

Kosman, M. (2013). Pogranicze w warsztacie politologa. Pogranicze. Polish Borderlands

Studies, $n r$ 1, s. 73.

Zacznę od uwagi natury ogólnej, związanej z dosyć często spotykaną w naszej dyscyplinie przesadną dbałością o jej „czystość”, co jest jednoznaczne $\mathrm{z}$ oddawaniem pola innym naukom humanistycznym (społecznym), które taką postawę przyjmują z wdzięcznością i ...pożytkiem, podejmując wymagające postawy interdyscyplinarnej tematy. Nierzadko jako ukoronowanie warsztatu twórczego traktuje się tzw. metodologię, i to w wydaniu nie wnoszącym wiele (nic?) nowego do dorobku politologicznego. Piszę o tym jako osoba (habilitacja 1971) określająca się jako historyk i (od ćwierćwiecza) politolog; która w kręgu universitatis dobrze się czuje również w korzystaniu z doświadczeń literaturoznawstwa czy socjologii. Po tym wstępie mogę stwierdzić, że inicjatywę powołania specjalistycznego czasopisma (może z czasem nie tylko w wersji internetowej - co piszę jako człowiek wychowany na tekstach drukowanych) przyjmuję z pełnym uznaniem i traktuję ją nie jako punkt wyjścia do przyszłych badań ale jako dobrze osadzoną już w dotychczasowym dorobku. Dokonania politologów środowiska opolskiego są w tym zakresie przekonującym dowodem.

O ile kresy w historii i legendzie (posługuję się tu tytułem własnej niedawnej publikacji) na pierwszym planie oddają pole historykom i literaturoznawcom, to $\mathrm{w}$ przypadku pogranicza, rzecz jasna wspomnianych nie wykluczając, na pierwszym planie należy dostrzegać socjologów i politologów, którzy czerpią z doświadczeń badaczy zamkniętej przeszłości, z kolei dostarczając tamtym wyników swych studiów nad współczesnością (l'histoire contemporaine, Zeitgeschichte) i prognozowaniem przyszłości.

Zagadnienie pogranicza należy dziś do zasadniczych tematów w badaniach humanistycznych (społecznych), zwłaszcza w warsztacie politologa. W odniesieniu do Polski jest to szczególnie ważne zważywszy skutki politycznych przemian granicznych, przede wszystkim na wschodzie i zachodzie. Nie potrzeba tego uzasadniać odpowiadając na inicjatywę zrodzoną w środowisku opolskim, które posiada bogaty dorobek z tego zakresu. Jak bardzo jest on złożony (interdyscyplinarność), niech świadczy dorobek czołowego jego przedstawiciela, badacza i pisarza, prof. Stanisława Niciei, któremu zawdzięczamy również gromadzenie unikalnej bazy źródłowej, uchronionej przed rozproszeniem, jeśli nie przed zanikiem. Na tym przykładzie widzimy, że pojęcie pogranicza ma charakter nie tylko stabilny ale wiąże się też ze skutkami wielkiej niedawnej „wędrówki ludów" i przemieszczeniami terytorialnymi. Współczesne przemiany cywilizacyjne z kolei pociągają za sobą wraz ze wzmożoną mobilnością nadawanie mu zupełnie innego niż dawniej charakteru.

Piszę o tym przede wszystkim w oparciu o wieloletnie refleksje na temat polskiej granicy wschodniej (kresów, pogranicza) $\mathrm{w}$ minionym tysiącleciu.

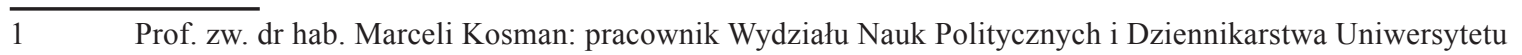
im. Adama Mickiewicza w Poznaniu. 